\title{
Plant protection and forest protection - the development of legislation and forest protection services in Poland
}

\author{
Elżbieta Karmiłowicz ${ }^{1}$, Iwona Skrzecz ${ }^{2} \bowtie$, Ewa Matyjaszczyk ${ }^{3}$ \\ ${ }^{1}$ Forest Research Institute, Doctoral Studies, Braci Leśnej 3, Sękocin Stary, 05-090 Raszyn, Poland \\ ${ }^{2}$ Forest Research Institute, Department of Forest Protection, Sękocin Stary, Braci Leśnej 3, 05-090 Raszyn, Poland, \\ phone: +48 22 7150541, fax: +48 22 7150557, e-mail: i.skrzecz@ibles.waw.pl \\ ${ }^{3}$ Institute of Plant Protection - National Research Institute, Władysława Węgorka 20, 60-318 Poznań, Poland
}

\section{Abstract}

The paper presents the history of legal changes regarding forest protection in Poland and the development of forest protection services Poland's accession to the European Union in 2004 has affected the marketing and the use of plant protection products (PPPs) in the country. The implementation of the EU legislation (Directive 91/414/EEC) has resulted in a decline in the assortment of pesticides registered for use in agriculture, and in forestry. This situation resulted from the limited interest of producers in placing PPPs on the market. Furthermore, limitations in the aerial application of PPPs have been introduced, which has consequences for the protection of the forest, where aerial treatments are often the only way to reduce the number of pests. On the other hand, the introduction of integrated pest management (also in forestry) confirmed the adequacy of activities carried out in the State Forest National Forest Holding, where, for many decades, the prevention methods have been used to increase the resistance of stands and the multi-stage Decision Support System (DSS) is used to select the optimal protective method.

\section{KeY WORDS}

forestry, forest protection, plant protection, plant protection products, legislation, integrated pest management, IPM, aerial treatments, insects, diseases

\section{INTRODUCTION}

The outbreaks of insects and tree diseases attacking stands on the area of many thousands of hectares belong to the most important problems of forest protection (Fleming and Candau 2004; Kolk 2006; Johnson et al. 2014). The outbreaks may result from the appearance of new or excessive development of earlier occurring species of insects and fungi. The protection of forest in- volves numerous activities, with crucial role of preventive measures. Chemical protection is only one of the methods of pest control used in the forestry when the other measures fail. However, the use of plant protection products (PPPs) has become an important element of forest management in the twentieth century. The use of PPPs in forests is subject to the same legal regulations that apply to agriculture, horticulture, vegetable growing and other crop production sections. 
The chemical forest protection is influenced by the availability of PPPs undergoing dynamic changes (Matyjaszczyk and Sobczak 2017a; Matyjaszczyk and Sobczak 2017b), which in turn are influenced by the increasing knowledge resulting from scientific research (Lorenzo and Kreutzweiser 2015). The pressure of the society demanding an environment free from pesticides is also important (Lamischane et al. 2016). Changes in the methods of plant protection, including forestry, are also a consequence of the implementation of legal regulations (Matyjaszczyk 2011a).

The impact of legislative changes into the use of PPPs in the agricultural production sector has already been the subject of many publications (Eurostat 2007; Matyjaszczyk 2011b), but there are no such studies in forestry. Therefore, the aim of this article is to present the most important changes in the legislation related to the use of PPPs during the past century together with a discussion of the consequences resulting from the introduction of the EU legislation into the practice of forest protection. In addition, the development of forest protection services in the analysed period was presented.

\section{Polish legislation before the accession to the European UnION}

\section{Interwar period (1918-1939)}

The first act of the Polish law concerning the use of PPPs was adopted in 1919 in the Basic Sanitary Law, which regulated issues such as clean air protection, water and soil protection, the cultivation and sale of medicinal plants. This act also included provisions for the competence of the Ministry of Public Health to supervise the sanitation of food cooperation in terms of 'food nutrition', which can be indirectly considered as the basis for future regulations in the scope of PPP application in agriculture.

The second act of law in the interwar period related to the plant protection was the Regulation of the Minister of Internal Affairs and the Minister of Industry and Trade of 1924 concerning the manufacture and sale of substances intended to poison rats, mice, insects, animal parasites and so on. This document regulated the rules of registration, such as the permission for marketing authorization and application of PPP, and specified the requirements for the content of labels, marking, storage and sale. This regulation is considered to be the beginning of the registration of PPP in Poland. However, the first act on plant protection is the Ordinance of the President of the Republic on the control of plant diseases and on the control of weeds and plant pests of 1927. This regulation provided definitions and methods of plant protection as well as the rights of the Minister of Agriculture in this respect. The authorities supervising plant protection issues were also identified, and the scope of their permissions to provide expertise and control of activities regarding plant protection against pests (insects, rodents), fungal diseases and weeds was specified.

\section{Post-war period (after 1945)}

In Poland, after the Second World War, the activities in the field of PPP registration were regulated for the first time by the act on the protection of crop plants against diseases, pests and weeds of 1956. This law defined PPPs as substances used to weed destruction and plants colonised by pests or infected by bacteria, viruses or fungi. On the other hand, plant protection measures that prevented the spread of organisms from other countries and resulted in their localisation and disposal were referred to as plant quarantine. The basic methods of plant protection were also described, dividing them for the first time into mechanical, agrotechnical, biological and chemical methods.

The next legislative act regulating the use of pesticides was the Decree of the Minister of Agriculture of 1960 on the conditions for the release of PPPs. This regulation provided the definition of PPPs for the first time: 'all articles of synthetic and natural origin intended to the control plant diseases and weeds, and to protect plant products during their storage, processing, vegetation, as well as the products and preparations used for sanitary purposes' were considered as PPPs. This decree clarified the issues concerning the testing and admission of PPP on the Polish market. This document also contained a statement that only substances authorised by the Minister of Agriculture might be admitted for marketing and use.

The act from 1961 on the protection of crop plants against diseases, pests and weeds was another very important step in the development of plant protection in Poland, which was the first legal act in the rank of a law 
containing regulations on registration of PPPs (Pruszynski and Błochowiak 2013). In addition to the general rules, it contained detailed guidelines on the control of diseases, pests and weeds; quarantine of plants; and the ways in which it is applied. The provisions of this law imposed the necessity of having the permission of the Minister of Agriculture to introduce plant protection chemicals (chemical PPP) on the market.

On the basis of the Act of 1961, the Decree of the Minister of Agriculture was issued in 1965 on the conditions and procedure of granting permits for commercialisation of chemical PPPs. This decree specified the requirements for producers of chemicals applying for a permanent or temporary authorisation of a preparation to place it on the market. Amongst the conditions of admission, there were the need to use the new packaging and labels of the toxicity. There was a classification of PPPs into five classes of toxicity. The provisions of this decree obliged the Ministry of Agriculture to annually publish a list of PPPs that had a permission to be placed on the market.

The legislation concerning the application of PPPs in the next years was mostly influenced by Directive 91/414/EEC - very important act of law changing the rules for the use of PPPs in the European Union, which was in force since 1993. It was issued in order to harmonise the regulations on marketing and use of PPPs all over the European Union. According to this directive, active substance should be authorised by the European Commission on the basis of a common procedure, which was included in the Member States. The standardised regulations provided placing to the marketing and use PPPs, which have been thoroughly researched, considering their effectiveness and possible risks to human health, animals and the environment (Czaplicki et al. 1995). Hence, Directive 91/414/EEC states that 'the protection of humans and animals and of the environment takes priority over the improvement of the level of agricultural production'.

In spite of Poland not being at that time an EU member, Directive 91/414/EEC has stimulated the development in Poland the new Act on the protection of crops from 1995 and the Regulation of the Minister of Agriculture and Food Economy of 1996. The most important changes in both acts included the introduction of the obligation to apply PPPs in accordance with the Principles of Good Plant Protection Practice and new rules of PPP classification for people, bees, fish and other aquatic organisms. An important bequest was the creation of the State Plant Protection and Seed Inspection. The document required the use of PPPs according to the label instructions so as not to endanger the health of people, animals and environmental contamination. Using of biological, cultivating and agro-technical methods of plant protection were obligatory and applied at first. It allowed to limit the use of chemical pesticides to the minimum necessary. These provisions were maintained in subsequent plant protection laws, and they were supplemented later by integrated methods.

Much more requirements of Directive 91/414/EEC have been implemented to Polish law in the Plant Protection Act of 2003 (it means before accession of Poland to the European Union in May 2004). This document introduced the registration of PPPs for a maximum period of 10 years. It also authorised the use of PPPs for 18 months after the expiry date of the permission. In addition, it was possible to use the PPPs for a limited period in crops growing on small areas or against harmful organisms causing losses in specific areas. The act included a single permission for using of PPPs for a period not longer than 120 days. It was concerned to preparations that did not meet the requirements for the admission of use. The same act of law specified the conditions of application PPPs by aerial equipment and land-based application of pesticides.

\section{Legislation after Poland's accession to the EUROpeAN UNION (2004)}

Currently, the rules regarding pesticide application in Poland is influenced by the following legal acts and thematic concepts:

- Thematic Strategy on the Sustainable Use of Pesticides,

- Directive 2009/128/EC of the European Parliament and of the Council of 21 October 2009 establishing a framework for community action to achieve the sustainable use of pesticides (known as Directive 2009/128/WE),

- Regulation (EC) No. 1107/2009 of the European Parliament and of the European Council of 21 October 2009 concerning the placing of protection products on the market and repealing Council Directives 
79/117/EEC and 91/414/EEC (known as Regulation 1107/2009),

- The Plant Protection Act of 8 March 2013.

\section{Thematic Strategy on the Sustainable Use of Pesticides}

Despite the legislative acts aimed at the protection of animals, human health and environment, no actual reduction of the amount of PPP use was observed between 1992 and 2003 within the European Union. To counteract this tendency, on 12 July 2006, the European Commission published a Thematic Strategy on the Sustainable Use of Pesticides. Its main purpose was to reduce the level of threats to human health and the environment related to the use of pesticides, through their sustainable use, and to reduce the use of chemicals to the necessary minimum. This strategy has created the basis for the legislative actions that resulted in the publication of four documents in 2009. The most important documents for sellers and users of PPPs were Directive 2009/128/EC and Regulation 1107/2009.

\section{Directive 2009/128/WE and Regulation 1107/2009}

These documents established a common legal framework for the sustainable use of pesticides in EU Member States. Their objective is to ensure a high level of protection of human health, animals and environment through the introduction of the EU-wide legislation concerning trading, application, monitoring and supervising of PPP use. In order to reduce the risks associated with the use of pesticides, both acts have mandated the use of PPP in accordance with the principles of good plant protection practice and the principles of integrated pest management listed in Annex III of Directive 2009/128/EC.

From the forest protection point of view, one of the most important provisions of Directive 2009/128/EC is the ban on the use of PPPs by aerial spraying with the exception when it diminishes the negative influence of pesticides on human health and environment or when it is impossible to use an alternative method. An equally important provision of Regulation 1107/2009 for foresters is the possibility to obtain a permit to extend the authorisation of PPP trading, concerning the PPPs already registered in a Member State, for their minor use. Moreover, in exceptional circumstances, for example, in the case of a danger that cannot be prevented in any different way, a Member State may authorise the PPP trading for a period of up to 120 days for the purpose of limited and controlled use (the so-called derogation). An example of such danger is a large-area outbreak of forest insects.

\section{Plant Protection Act of 8 March 2013}

Owing to the wide range of changes in legal regulations resulting from the abovementioned documents and the necessity of their introduction into national legislation, there was a need to develop a new act on PPPs related to their use in Poland. Thus, the next Act of 8 March 2013 implemented the provisions of the Directive 2009/128/ EC and Regulation 1107/2009.

\section{THE CONSEQUENCES OF INTRODUCING NEW EUROPEAN UNION RULES FOR FOREST PROTECTION PRACTICE}

\section{Reduction of the number of plant protection products registered for forestry}

Legal changes in the use of pesticides in the European Union contributed to the withdrawal of a large group of active substances that could be dangerous to humans or the environment, including those with a long-term degradation and adversely affecting non-target (beneficial) insects, and, as a consequence, PPPs containing them from the market (Matyjaszczyk 2011). The most stringent criteria were for insecticides, which by their action more often than other PPPs were classified as toxic to humans. Unfortunately, the high costs of the re-evaluation of many active substances led to their withdrawal from the market, especially those produced by the small companies. Prize of new authorisation for this kind of PPPs did not compensate the financial costs incurred for re-evaluating them, especially for small-scale producers, for example, biological PPPs.

All these changes resulted in the reduction of nearly $70 \%$ of the PPPs registered for the protection of forest areas (Fig. 1) (Karmiłowicz et al. 2017). In this way, the registration of PPPs for forests occupying a small area, compared to agricultural crops, has become unprofitable. In 2016, the National Forest Holding State Forests (hereinafter referred to as the State Forests) had only three PPPs authorised for use in aerial spraying. These were Dimilin 480 SC (active substance - diflubenzu- 




Figure 1. Number of insecticides registered for aerial treatments in forests in the years 1997-2017 in Poland

ron), Mospilan 20 SP (acetamiprid) and Foray 76 B (Bacillus thuringiensis). Such significant reduction in the range of PPPs can lead to the development of insect resistance to insecticides in the future (Skrzecz and Perlińska 2016).

A positive aspect of Regulation 1107/2009 is the possibility to apply for the extension of the authorisation of a PPP registered in a given Member State for minor uses, not yet covered by this authorisation (Matyjaszczyk 2012). The derogation concerning minor uses allowed the State Forests for using several fungicides and insecticides in small-area crops, for example, in nurseries, in plantations of seed trees and in reforestations.

\section{New rules for aerial sprayings}

In 2016, the forest area in Poland amounted to more than 9,200,000 ha, of which 77\% were under the management of the State Forests (Milewski 2016). As mentioned earlier, one of the most important problems of forest protection in Poland is the outbreaks of leaf-eating insects, cyclically occurring on the areas of up to several hundred thousand hectares. They cause damage and, in extreme cases, total defoliation leading to dieback of tree stands. Therefore, new regulations are particularly important for the State Forests, specifying the preparation of aerial treatment plans and conditions for obtaining an agreement for their implementation. According to the Act of 8 March 2013, PPPs may be used with the use of aerial equipment if the control of harmful organisms is not possible by using land-based equipment and also if the use of PPPs by aerial sprayings causes less risk to human and animal health or for the environment than land-based equipment. Aerial use of herbicides, desiccants and PPPs that involve a risk to human or animal health is forbidden.

The current procedures put requirements on the State Forests to prepare an aerial spraying plan with the use of PPP, which must be submitted to the Voivodeship Inspector of Plant Health and Seed Inspection up to 40 days before of this activity. The plan provides justification for the necessity to perform the treatments and information on the harmful organisms to be controlled, the area covered by the planned treatment, the species of plants subject to the treatments, the planned dates of the treatments with the name of PPP and the manner of warning of people and owners of animals that may be at a risk of contact with the pesticide as a result of the planned treatments. To the treatment plan, the entity planning the treatment includes a statement of the technical conditions of the equipment and its use. Then the Voivodeship Inspector approves the treatment plan within 7 working days of the date of submission of the treatment plan if the conditions set out in this Act and Regulation No. 1107/2009 have been met. Within 7 days before the planned date of treatment, the entity planning the aerial sprayings informs the Voivodeship Inspector about the intention to carry out such operations included in the treatment plan. After 3 days from the date of receipt of this, the Voivodeship Inspector may prohibit 
the treatments if the indicated PPPs cannot be applied with the use of aerial spraying equipment or in the area cannot be treated.

In the case of an unforeseen threat from harmful insects, it is possible to carry out an aerial spraying treatment not included in the treatment plan if it does not cause a risk to human health, animals or the environment. In this case, the entity planning the treatment informs the Voivodeship Inspector about the intention to carry out such sprayings within 7 days before the intended treatment date with the required information. Then the Voivodeship Inspector within 3 days may prohibit the treatment too. He also provides information on the planned aerial spraying operations on the website of the Voivodeship Inspectorate of Plant Health and Seed Inspection.

\section{Integrated pest management in forestry}

On 1 January 2014, Directive 2009/128/EC ordered the users of pesticides, including the State Forests, to apply the general principles of integrated pest management specified in Annex III of this directive.

In integrated pest management, the main goal of all treatments remains the plant, its genetic properties and the response to the organisms that inhabit it, as well as its connections with the environment (Głowacka et al. 2013). A very important element of this concept is the prevention and protection operations, in which priority is given to mechanicals, biological and biotechnical method involving the use of traps, biological insecticides and substances that affect insect behaviour, such as pheromones and kairomones. Whilst chemical treatments are used after exhausting other methods and in cases that threaten the sustainability of crops.

Contemporary forest protection is based on the strategy of integration of various methods to keep the population of harmful insects and fungal pathogens below the level of economic threshold (Skrzecz 2017). In forestry practice, prophylactic activities are aimed at strengthening the resistance of stands to attacks by insects or pathogens and take into account the recommendations in the field of forest silviculture, utilisation and protection. In the idea of integrated pest management used in Polish forestry, the choice of protection method is influenced by the multi-stage Decision Support System (DSS), which includes identification of the pest, the area of its abundance, the level of threat to stands as well as the estimation of damage and possible losses (Fig. 2). It is also important to identify the coexistence of a species with other species of harmful insects. At the final stage of DSS, the available protection methods are reviewed and the most appropriate method in the given conditions is chosen.

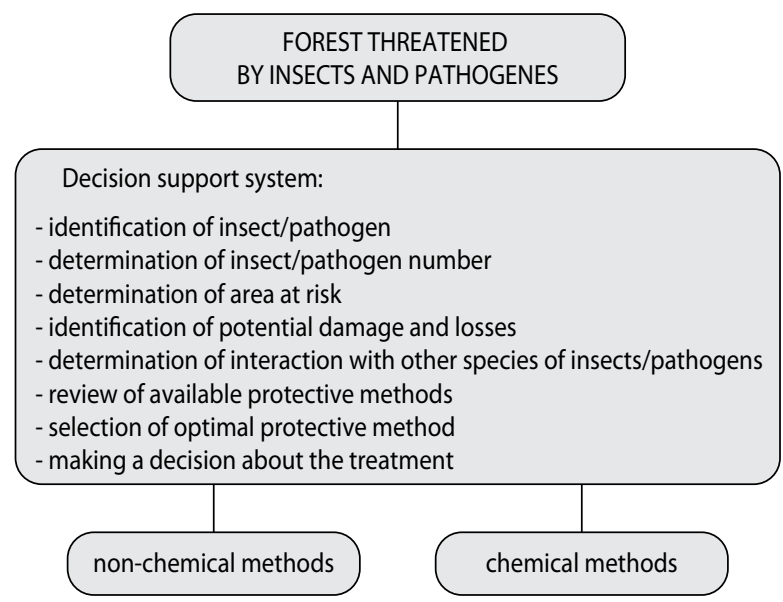

Figure 2. Decision Support System used in forest protection against insects and pathogens

\section{Development of forest protection services}

The organisation of forest protection services in Poland has begun in 1930, when the Experimental Unit of State Forests was established to conduct research for forests destroyed during the First World War and weakened by insect gradations. At the beginning of this unit's activity, Department of Insect and General Protection and Department of Phytopathology were separated. Then in 1934, the Experimental Unit of State Forests was transformed into the Forest Research Institute, in which Department of Forest Protection and Department of Plant Disease Control were created (Głowacka 2001). In the large-scale outbreak of pine beauty moth Panolis flammea (Denis \& Schiffermüller) on 400,000 ha in the first half of the $1920 \mathrm{~s}$, the main problem of forest protection has become mass occurrences of harmful forest insects. One of the first steps in close cooperation with forestry practice was to organise an information emergency, in which attempts were made to control pests, and the knowledge about it was promoted in the form of training, leaflets, brochures and keys for insect describ- 
ing. The studies and expertise on forest phytopathology belonged to the one of the most important tasks for forestry practice. They concerned solving the current problems caused by fungi in forest nurseries and plantations including determination of pathogen species as well as methods of timber protection against blue stain in forest depots.

In the post-war period, the problems with the outbreaks of harmful insects appeared again, especially in the western and northern parts of the country, where the large areas of poor habitats were reforested. Thus, the Forest Research Institute, which was reactivated after Second World War, and with units renamed to the Department of Forest Protection and Department of Plant Diseases, took over the role of the emergency service. In addition to research, their activities included cooperation with the State Forests in the assessment of forest health, consultancy and training on methods of forest protection, including those aimed at the reduction of pest numbers. At the same time, particular emphasis was placed on the comprehensive application of different preventive methods to limit the development of insect outbreaks.

Owing to the large number of pest-related problems, it became necessary to establish additional forest protection services (Gawęda 1995). Therefore, in 1954, the director of State Forests established four Forest Protection Divisions: in northern Poland (in Gdańsk) and in the west (in Poznań) and the south of the country (in Opole and Kraków) (Żakowski 1992). These divisions covered significant areas of Poland, with the exception of the State Forests in the centre (Łódź and Siedlce) and in the east of the country (Lublin), where the Forest Research Institute was still involved in forest protection. In subsequent years, further divisions were established (in narrowing the areas of their activities), and the researchers from the Institute focused on scientific studies developed new methods of forest protection. In addition, in the 1960s-1980s, there was a scientific board supporting the actions of aerial treatments of forests threatened by leaf-eating insects.

Since 1992, nine Forest Protection Divisions have been operating in Poland: in north: Szczecinek (geographical coordinates 53.710071, 16.699360), Gdańsk (54.352025, 18.646638) and Olsztyn (52.229676, 21.012228); in the centre: Łopuchówko (52.590939, 17.087517), Łódź, (51.759248, 19.455983), Ra- dom (51.402723, 21.147133) and Lublin (51.246453, 22.568446); in the south: Wrocław (51.107885, 17.038537), Opole (50.675106, 17.921297) and Kraków $(50.064650,19.944979)$, where in total 40 people work together. They are located in the organisational structure of the General Directorate of the State Forests (Fig. 3). Their most important task is to monitor the healthy status of forests and identify their threats from biotic, abiotic and anthropogenic factors and recommend remedies. Also the function of mentioned divisions is consultancy and giving the advices based on field observations and expertise, as well as organisation of trainings on the forest protection, including the preparation of training materials and publications. Members of Forest Protection Divisions closely cooperate with scientific units, constantly expanding the knowledge and raising up their qualifications. In addition, the Forest Protection Divisions cooperate with the Forest Protection Departments located in 17 Regional Directorates of State Forests that are organisational units of the State Forests. These Departments are responsible for the organisation of pest treatments with the use of PPPs, including contact with Voivodeship Inspectorates of Plant Health and Seed Inspection in the cases concerning aerial spraying. In addition, these Departments, similar to the Forest Protection Divisions, deal with practically whole spectrum of issues related to the forest protection.

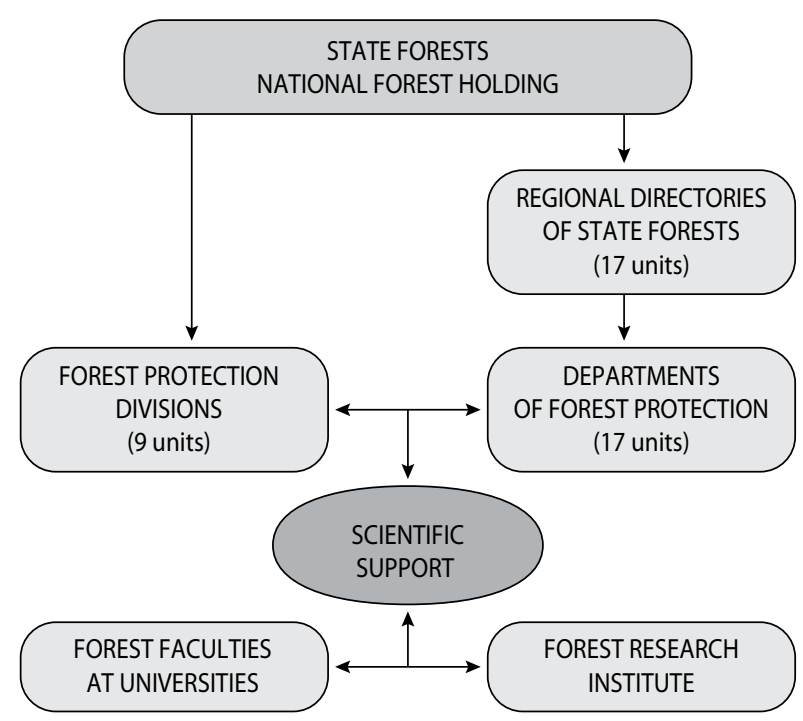

Figure 3. Organization of Forest Protection Service in Poland 


\section{Conclusions}

The beginning of the legislation concerning the use of PPPs in Poland dates back to the 1920s. During this time, subsequent changes in the regulations aimed at unifying the rules on the marketing and use of pesticides in the country. In the European Union, the most important changes in this area were introduced in 1991 under Directive 91/414/EEC, which introduced new requirements for the marketing and using of PPPs with high standards regarding human and animal health and natural environment safety. Compliance with these requirements resulted in a significant increase of costs associated with the registration of PPPs, which led to the elimination of many pesticides produced by small- and medium-sized companies. As a result, the range of pesticides registered for the protection of large-area crops in agriculture and forestry has fallen.

Contemporary plant protection in Poland has been strongly influenced by Poland's accession to the European Union. At present, the most important legislation regulating the marketing and use of PPPs in country is Directive 2009/128/EC of the European Parliament and of the Council of 2009, Regulation (EC) No 1107/2009 of the European Parliament and of the Council of 2009 and the Plant Protection Act of 8 March 2013. The implementation of these acts into the practice of forest protection against insects and pathogenic fungi resulted in (1) a significant reduction in the number of pesticides registered for using in forestry, (2) changes in the procedures applicable to aerial sprayings of insecticides and (3) the obligation to implement integrated pest management in forestry.

\section{Acknowledgements}

The publication was financed from own sources of the Forest Research Institute and by the General Directorate of State Forests in Poland, project no. BLP 394.

\section{References}

Brodziak, Ł., Głowacka, B., Hilszczański, J., Jabłoński, T., Łukaszewicz, J., Skrzecz, I. 2013. Methodology of integrated protection of coniferous stands.
Forest Research Institute. On-line: http://www. ibles.pl/web/guest/uslugi;jsessionid=dw86QWi6Pf 0xMnyetjrpCKSJ

Czaplicki, E., Podgórska, B., Rogalińska, M. 1995. 30 years of registration of plant protection products in Poland. Proceedings of 35. Scientific Session of Forest Research Institute, 1, 52-59.

Eurostat 2007. The use of plant protection products in the European Union. Available at: http://ec.europa. eu/eurostat/documents/3217494/5611788/KS-7606-669-EN.PDF

Fleming, R.A. Candau, J.-N. 2004. Climate change and insect outbreaks. In: Effects of climate change on major forest disturbances (fire, insects) and their impact on biomass production in Canada: Synthesis of the current state of knowledge (eds.: S. Gauthier, D. Gray, C. Li), 21 September 2004, 8-12.

Gawęda, P. 1995. About Forest Protection Division (in Polish). Echa Borów Nadbattyckich, 7, 5-7.

Głowacka, B. 2001. Development and achievements of the Forest Research Institute in the years 1930-2000 (in Polish), Vol. I-III.

Johnson, T.N., Buskirk, S.W., Hayward, G.D, Raphael, M., G. Tree mortality after synchronized forest insect outbreaks: Effects of tree species, bole diameter, and cutting history. Forest Ecology and Management, 319, 10-17. DOI: 10.1016/j. foreco.2014.01.0470378-1127.

Karmiłowicz, E., Skrzecz, I., Matyjaszczyk, E. 2017. Changes of active substances and their formulations used by aerial spraying in the protection of Polish forests against harmful insects (in Polish). Przemyst chemiczny, 96/12, 1000-1003. DOI: 10.15199/62.2017.12.XX.

Kolk, A. 2006. Insect outbreaks in managed and unmanaged forests. Forest Research Institute.

Lamichhane, J.R., Dachbrodt-Saaydeh, S., Kudsk, P., Messean, A. 2016. Toward a reduced reliance on conventional pesticides in European agriculture. Plant Disease, 100 (1), 10-24. DOI: 10.1094/PDIS05-15-0574-FE.

Lorenzo, F., Kreutzweiser, D. 2015. Alternatives to neonicotinoid insecticides for pest control: case studies in agriculture and forestry. Environmental Science and Pollution Research International, 22, 135-147. DOI: 10.1007/s11356-014-3628-7. 
Matyjaszczyk, 2011a. Selected aspects of plant protection in Poland, five years on from EU accession. Outlook on Agriculture, 40 (2), 119-123. DOI: 10.5367/oa.2011.0042.

Matyjaszczyk, E. 2011b. Analysis of changes in plant protection legislation in terms of food safety, people and the environment. Rozprawy Naukowe Instytutu Ochrony Roślin - PIB, Poznań.

Matyjaszczyk, E., Sobczak, J. 2017a. Novel insecticide active substances on the Polish market. Przemyst Chemiczny, 6, 1367-1369. DOI: 10.15199/62.2017.6.30

Matyjaszczyk, E., Sobczak, J. 2017b. Novel fungicide active substances on the Polish market (in Polish). Przemyst Chemiczny, 6, 1407-1409. DOI: 10.15199/62.2017.6.31

Milewski, W. 2016. Forests in Poland in 2016. State Forests Information Centre. Available at: http://www. lasy.gov.pl/pl/informacje/publikacje/in-english/ forests-in-poland/forests-in-poland-2016

Pruszynski, S., Błochowiak, A. 2013. The present problems of plant protection in Poland. Part I. History, Science, Education. Progress in Plant Protection/ Postęy w Ochronie Roślin, 53 (1), 196-201.

Skrzecz, I., Perlińska, A. 2016. Current problems of forest protection (in Polish). Proceedings of VIII Session of Winter Forest School in Forest Research Institute „Threats to the forest and its functions - causes, consequences and opportunities for forest management", 15-17 March 2016, 71-90.

Skrzecz, I. 2017. Directions of a development of forest protection methods (in Polish). Postępy Techniki w Leśnictwie, 138, 7-16.

Żakowski, H. 1992. Organizational and territorial shape of the Forest Protection System in Poland (in Polish). Sylwan, 2, 4-10. 